\title{
High-Density Lipoprotein Cholesterol and Apolipoprotein A-I Levels at Diagnosis in Patients with Non-Insulin Dependent Diabetes
}

\author{
K. G. Taylor, A. D. Wright, T. J. N. Carter, A. J. Valente, S. A. Betts, and K. A. Matthews \\ General Hospital, Birmingham, and Departments of Clinical Chemistry, Investigative Pathology, \\ and Statistics, Queen Elizabeth Medical Centre, Birmingham, England
}

\begin{abstract}
Summary. High-density lipoprotein (HDL) cholesterol levels were decreased in patients with non-insulin dependent diabetes at diagnosis when matched with a control population for sex, age, obesity, alcohol consumption and cigarette smoking. There was no association between serum HDL-cholesterol concentration and the percentage of glycosylated haemoglobin $\mathrm{A}_{1}\left(\mathrm{HbA}_{1}\right)$. Serum $\mathrm{HDL}$-cholesterol levels were lower in diabetics over the whole range of serum triglyceride levels, and particularly in hypertriglyceridaemic diabetics. Serum apolipoprotein A-I levels were not decreased in diabetics with normal serum triglyceride levels, so that the ratio of HDLcholesterol to apolipoprotein A-I was significantly decreased in diabetics $(p<0.005)$. Decreased HDLcholesterol levels in non-insulin dependent diabetes could be relevant to the subsequent development of atherosclerosis.
\end{abstract}

Key words: HDL-cholesterol, apolipoprotein A-I, non-insulin dependent diabetes, hypertriglyceridaemia.

Atherosclerosis is an important cause of premature mortality and morbidity among patients with both insulin-dependent and non-insulin dependent diabetes mellitus. Following the demonstration of a negative association between the risk of developing coronary heart disease and the serum HDL-cholesterol concentration in non-diabetic individuals [1], serum HDL-cholesterol levels in patients with diabetes have been measured by several investigators $[2$, $3,4]$. However, patients were not matched with randomly selected controls from a non-hospital population for age, obesity, alcohol consumption and cigarette smoking - all factors which have been shown to affect the serum HDL-cholesterol concentration $[1,5,6,7]$, or patients were studied retrospectively while receiving dietary or drug therapy. It is possible that the diets and drugs used to treat diabetes have an effect on HDL-cholesterol levels. Thus, treatment with sulphonylureas is associated with reduced serum HDL-cholesterol levels [3].

The purpose of our study was to establish whether patients with non-insulin dependent diabetes have decreased serum HDL-cholesterol levels at diagnosis by comparing them with a non-hospital population matched for the above factors. Furthermore, we wished to compare apolipoprotein A-I and HDL-cholesterol in non-insulin dependent diabetics and controls, following the previous finding that HDL-cholesterol levels were decreased, but apolipoprotein A-I levels unchanged in treated diabetics [2].

\section{Materials and Methods}

\section{Populations}

One hundred and thirty-one newly presenting patients under the age of 65 years, consecutively attending the diabetic clinic, were selected for the study if their random capillary blood glucose was above $10 \mathrm{mmol} / \mathrm{l}$ and their fasting capillary blood glucose was above $7 \mathrm{mmol} / \mathrm{l}$. The purpose of the study was explained and if verbal consent was given they attended an early morning clinic after a $12 \mathrm{~h}$ fast, when blood was collected for determination of serum total cholesterol, triglyceride, HDL-cholesterol, apolipoprotein $\mathrm{A}-\mathrm{I}$ and $\mathrm{HbA}_{1}$. A medical history was taken, including tobacco and alcohol consumption, and full clinical examination performed. Patients were excluded if they were receiving thiazide diuretics, beta-blockers or the contraceptive pill, or if there was laboratory evidence of renal or hepatic impairment.

The control population consisted of 408 individuals selected randomly from the workforce of a local factory. All these subjects were under 65 years of age, known diabetics were excluded and all 
Table 1. Clinical and biochemical data on non-insulin dependent diabetic and control subjects

\begin{tabular}{|c|c|c|c|c|}
\hline & \multicolumn{2}{|l|}{ Males } & \multicolumn{2}{|l|}{ Females } \\
\hline & $\begin{array}{l}\text { Diabetics } \\
(71)\end{array}$ & $\begin{array}{l}\text { Controls } \\
(189)\end{array}$ & $\begin{array}{l}\text { Diabetics } \\
(60)\end{array}$ & $\begin{array}{l}\text { Controls } \\
(219)\end{array}$ \\
\hline Age (years) & $51 \pm 10^{\mathrm{b}}$ & $38 \pm 13^{b}$ & $52 \pm 9^{\mathrm{b}}$ & $43 \pm 12^{b}$ \\
\hline \%desirable body weight & $121 \pm 18^{\mathrm{b}}$ & $113 \pm 13^{b}$ & $140 \pm 28^{b}$ & $121 \pm 21^{b}$ \\
\hline Fasting blood glucose (mmol/1) & $11.4 \pm 3.3$ & $4.7 \pm 0.5$ & $11.6 \pm 3.8$ & $4.5 \pm 0.5$ \\
\hline $\mathrm{HbA}_{1} \%$ & $13.4 \pm 3.0$ & $7.6 \pm 0.9$ & $13.7 \pm 3.0$ & $7.9 \pm 0.9$ \\
\hline Serum total cholesterol $(\mathrm{mmol} / \mathrm{l})$ & $5.8 \pm 1.3^{\mathrm{a}}$ & $5.5 \pm 1.2^{\mathrm{a}}$ & $5.8 \pm 1.4$ & $5.7 \pm 1.2$ \\
\hline Serum triglyceride $(\mathrm{mmol} / 1)$ & $2.31 \pm 1.49^{b}$ & $1.48 \pm 1.04^{\mathrm{b}}$ & $1.83 \pm 1.24^{b}$ & $1.17 \pm 0.63^{b}$ \\
\hline Serum HDL-cholesterol (mmol/1) & $0.99 \pm 0.28^{\mathrm{b}}$ & $1.16 \pm 0.24^{\mathrm{b}}$ & $1.16 \pm 0.36^{\mathrm{b}}$ & $1.39 \pm 0.31^{b}$ \\
\hline \multirow[t]{2}{*}{ Serum apolipoprotein $A-I(g / l)$} & \multirow{2}{*}{\multicolumn{2}{|c|}{$1.12-0.21$}} & $1.16 \pm 0.18$ & $1.24 \pm 0.36$ \\
\hline & & & \multicolumn{2}{|c|}{ NS } \\
\hline
\end{tabular}

Numbers of subjects in parentheses. ${ }^{a} \mathrm{p}<0.05 ;{ }^{b} \mathrm{p}<0.001$

Table 2. Clinical and biochemical data on matched diabetic and control subjects

\begin{tabular}{|c|c|c|c|c|c|}
\hline & \multicolumn{2}{|l|}{ Males } & \multicolumn{3}{|l|}{ Females } \\
\hline & $\begin{array}{l}\text { Diabetics } \\
(39)\end{array}$ & $\begin{array}{l}\text { Controls } \\
\text { (39) }\end{array}$ & $\begin{array}{l}\text { Diabetics } \\
(44)\end{array}$ & & $\begin{array}{l}\text { Controls } \\
(44)\end{array}$ \\
\hline Age (years) & \multicolumn{2}{|l|}{ reta } & $52 \pm 9$ & \multicolumn{2}{|l|}{ NS } \\
\hline \%desirable body weight & \multicolumn{2}{|l|}{$1,0-17$} & $135 \pm 26$ & \multicolumn{2}{|r|}{$134 \pm 24$} \\
\hline Fasting blood glucose (mmol/l) & $11.4 \pm 3.2$ & $4.7 \pm 0.5$ & $11.6 \pm 3.7$ & & $4.5 \pm 0.5$ \\
\hline $\mathrm{HbA}_{1} \%$ & $13.4 \pm 2.3$ & $7.7 \pm 0.9$ & $13.8 \pm 3.1$ & & $7.9 \pm 0.9$ \\
\hline Serum total cholesterol (mmol/1 & 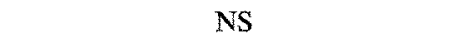 & $6.0 \pm 1.3$ & \multicolumn{3}{|c|}{ NS } \\
\hline Serum triglyceride $(\mathrm{mmol} / \mathrm{l})$ & \multicolumn{2}{|l|}{$2.13 \pm 1.48$} & $1.65 \pm 1.06$ & NS & $1.32 \pm 0.73$ \\
\hline $\begin{array}{l}\text { Serum HDL-cholesterol (mmol/l) } \\
\text { Serum apolipoprotein A-I }(\mathrm{g} / \mathrm{l})\end{array}$ & $\begin{array}{l}1.00 \pm 0.32^{\mathrm{a}} \\
1.09 \pm 0.18\end{array}$ & $\begin{array}{l}1.13 \pm 0.24^{\mathrm{a}} \\
1.14 \pm 0.21\end{array}$ & $\begin{array}{l}1.21 \pm 0.37^{\mathrm{a}} \\
1.18 \pm 0.18\end{array}$ & & $\begin{array}{l}1.36 \pm 0.33^{\mathrm{a}} \\
1.16 \pm 0.23\end{array}$ \\
\hline & \multicolumn{2}{|c|}{ NS } & \multicolumn{3}{|c|}{ NS } \\
\hline
\end{tabular}

Numbers of subjects in parentheses. ${ }^{a} \mathrm{p}<0.05$

had fasting blood glucose concentrations less than $6 \mathrm{mmol} / 1$. They were interviewed by a registered nurse about smoking, alcohol consumption and whether they were receiving any of the abovementioned drugs. Height and weight were recorded at this time. Blood was collected from these controls after a 12-h fast for the same determinations as in the diabeties.

The diabetics were matched with the controls using a computer programme for sex, age within 5 years, obesity (expressed as percent desirable weight) within $10 \%$, alcohol consumption and smoking habits. Percent desirable weight was derived from tables (Documenta Geigy, 1973). Alcohol consumption was classified into four groups: non-drinkers, light drinkers (one drink every day or one drinking session per week), moderate drinkers (two drinks every day or two drinking sessions per week) and heavy drinkers (more than two drinks every day or more than two drinking sessions per week). A non-smoker was a person who had not smoked for five years. All others were classified as smokers, so that the smoking group included subjects who had recently stopped smoking as well as current smokers. The groups were of comparable age and percent desirable weight (Table 2).
The populations of diabetics and controls were divided into three groups on the basis of serum triglyceride concentrations: those subjects with serum triglycerides $<1.5 \mathrm{mmol} / \mathrm{l}$, $1.5-3.0 \mathrm{mmol} / 1$ and $>3.0 \mathrm{mmol} / 1$ (Table 3 ).

\section{Assays}

Serum triglycerides were measured using an automated enzymic procedure $[8,9]$. Serum total cholesterol was measured by a manual enzymic procedure $[10,11]$ and HDL-cholesterol by the same technique after precipitation of the very-low-density and lowdensity lipoproteins (VLDL and LDL) using a sodium phosphotungstate-magnesium chloride reagent $[12,13]$. The intra- and inter-assay coefficients of variation for serum HDL-cholesterol were $1.5 \%$ and $3 \%$, respectively. To ensure completeness of precipitation of VLDL and LDL, representative HDL-containing supernatant fluids were checked to see they did not contain apolipoprotein B [14]. Apolipoprotein A-I was measured by onedimensional electroimmunodiffusion on whole serum [14]. Intra- 
Table 3. Serum HDL-cholesterol and apolipoprotein A-I levels in diabetic and control subjects grouped according to the serum triglyceride concentration

\begin{tabular}{|c|c|c|c|c|c|}
\hline & \multicolumn{2}{|l|}{ Males } & \multicolumn{2}{|l|}{ Females } & \multirow{2}{*}{$\begin{array}{l}\text { Serum triglyceride } \\
\text { range (mmol/l) }\end{array}$} \\
\hline & Diabetics & Controls & Diabetics & Controls & \\
\hline$\%$ desirable body weight & $116 \pm 15^{\mathrm{a}}(23)$ & $110 \pm 12^{a}(121)$ & $132 \pm 28^{b}(32)$ & $120 \pm 21^{b}(170)$ & \multirow{4}{*}{$<1.5$} \\
\hline Serum triglyceride $(\mathrm{mmol} / \mathrm{l})$ & $1.13 \pm 0.25(23)$ & $0.94 \pm 0.28(121)$ & $1.01 \pm 0.31(32)$ & $0.92 \pm 0.30(171)$ & \\
\hline Serum HDL-cholesterol $(\mathrm{mmol} / \mathrm{l})$ & $1.15 \pm 0.31(23)$ & $1.20 \pm 0.25(121)$ & $1.27 \pm 0.38^{\mathrm{b}}(32)$ & $1.44 \pm 0.30^{b}(170)$ & \\
\hline Serum apolipoprotein A-I (g/1) & $1.27 \pm 0.18^{\mathrm{a}}(23)$ & $1.15 \pm 0.24^{a}(115)$ & $1.18 \pm 0.16(32)$ & $1.22 \pm 0.20(168)$ & \\
\hline \%desirable body weight & $122 \pm 14(30)$ & $118 \pm 14(54)$ & $151 \pm 28^{b}(21)$ & $123 \pm 23^{b}(41)$ & \multirow{4}{*}{$1.5-3.0$} \\
\hline Serum triglyceride $(\mathrm{mmol} / \mathrm{l})$ & $2.07 \pm 0.45(30)$ & $2.03 \pm 0.40(50)$ & $2.17 \pm 0.46(21)$ & $1.89 \pm 0.30(42)$ & \\
\hline Serum HDL-cholesterol $(\mathrm{mmol} / \mathrm{l})$ & $0.95 \pm 0.25^{b}(30)$ & $1.11 \pm 0.21^{0}(54)$ & $1.09 \pm 0.28(21)$ & $1.19 \pm 0.25(42)$ & \\
\hline Serum apolipoprotein $\mathrm{A}-\mathrm{I}(\mathrm{g} / 1)$ & $1.16 \pm 0.26(30)$ & $1.13 \pm 0.19(53)$ & $1.22 \pm 0.15(21)$ & $1.31 \pm 0.71(42)$ & \\
\hline \%desirable body weight & $127 \pm 26(17)$ & $119 \pm 14(12)$ & $147 \pm 19(7)$ & $124 \pm 17(5)$ & \multirow{4}{*}{$>3.0$} \\
\hline Serum triglyceride $(\mathrm{mmol} / \mathrm{l})$ & $4.32 \pm 1.65(17)$ & $4.50 \pm 1.43(12)$ & $4.54 \pm 1.13(7)$ & $3.72 \pm 0.53(5)$ & \\
\hline Serum HDL-cholesterol (mmol/l) & $0.82 \pm 0.15^{\mathrm{a}}(17)$ & $0.98 \pm 0.23^{a}(12)$ & $0.79 \pm 0.11^{\mathrm{b}}(7)$ & $1.29 \pm 0.35^{b}(5)$ & \\
\hline Serum apolipoprotein $\mathrm{A}-\mathrm{I}(\mathrm{g} / \mathrm{I})$ & $1.09 \pm 0.16(17)$ & $1.15 \pm 0.19(12)$ & $0.92 \pm 0.21^{b}(7)$ & $1.28 \pm 0.07^{\mathrm{b}}(5)$ & \\
\hline
\end{tabular}

Numbers of subjects in parentheses. ${ }^{a} \mathrm{p}<0.05 ;{ }^{b} \mathrm{p}<0.01$

Table 4. Ratio of HDL-cholesterol to apolipoprotein A-I in matched diabetic and control subjects

\begin{tabular}{|c|c|c|c|c|}
\hline & \multicolumn{2}{|l|}{ Males } & \multicolumn{2}{|l|}{ Females } \\
\hline & Diabetics & Controls & Diabetics & Controls \\
\hline$\frac{\text { HDL-cholesterol }}{\text { Apolipoprotein A-I }}$ & $0.91 \pm 0.20^{\mathrm{a}}(39)$ & $1.01 \pm 0.16^{\mathrm{a}}(39)$ & $1.02 \pm 0.24^{\mathrm{a}}(44)$ & $1.19 \pm 0.23^{a}(44)$ \\
\hline
\end{tabular}

Number of subjects in parentheses. Significance of difference determined by Mann-Whitney $U$ test. ${ }^{a} p<0.005$

and inter-assay coefficiens of variation for serum apolipoprotein A-I were less than $10 \%$. The percentages of glycosylated haemoglobin $\left(\mathrm{HbA}_{1}\right)$ present in hacmolysates of blood from the diabetic patients were determined using a modification of a microcolumn method [15].

\section{Statistical Analyses}

Results are presented as mean \pm SD. The data were analysed using a statistical computer package implemented on the University of Birmingham's ICL 1906 A machine. Comparisons between means were made with Student's unpaired t test after it had been shown that the distributions of the data were statistically reasonably normal.

\section{Results}

Both male and female diabetic patients had lower HDL-cholesterol levels than the controls $(\mathrm{p}<0.001)$ (Table 1). There was, however, no significant difference in serum apolipoprotein A-I concentrations. The diabetics were significantly older, more obese and more hypertriglyceridaemic than the controls. However, in the matched diabetics and controls there was no significant difference between the serum tri- glyceride levels, and yet serum HDL-cholesterol levels remained lower in both male and female diabetics when compared to controls $(p<0.05)$ (Table 2). Once again the serum apolipoprotein A-I levels were not significantly different.

When the diabetic patients and controls were divided into three groups according to serum triglyceride levels, the diabetics had lower HDL-cholesterol levels over the whole range of triglyceride concentrations, although the differences did not always reach statistical significance in both sexes. In none of the groups was there a significant difference in mean triglyceride levels between controls and diabetics (Table 3). When serum triglycerides exceeded $3 \mathrm{mmol} / \mathrm{l}$, HDL-cholesterol levels were significantly lower in the diabetics, both male and female. Differences in serum apolipoprotein A-I levels only paralleled differences in serum HDL-cholesterol in females with triglycerides exceeding $3.0 \mathrm{mmol} / 1$.

The ratio of HDL-cholesterol to apolipoprotein A-I in the matched diabetics and controls, as shown in Table 4, was significantly lower in the diabetics $(\mathrm{p}<0.005)$.

There were no significant correlations between $\% \mathrm{HbA}_{1}$ and serum HDL-cholesterol or apolipopro- 
tein A-I levels, nor were fasting blood glucose levels correlated to serum HDL-cholesterol or apolipoprotein A-I concentration.

\section{Discussion}

The highly significant difference between serum HDL-cholesterol levels in patients with non-insulin dependent diabetes and controls (Table 1) has been shown in earlier studies $[2,3,4]$, but these studies did not examine patients at the time of diagnosis, before therapy had commenced. The diabetic patients were approximately a decade older than the controls and significantly more obese. In an earlier study on the control population we have shown that serum triglyceride levels increase with age, although there was no relationship between serum HDL-cholesterol and age [17]. In men there was a significantly positive correlation between serum triglyceride levels and obesity expressed as percent desirable weight, but this was not seen in women. No relationship was demonstrated between HDL-cholesterol and obesity. Furthermore, there was an inverse relationship between HDL-cholesterol and triglyceride in both sexes, as shown by other workers [16]. Thus, the differences between HDL-cholesterol levels in patients with diabetes and the controls could be explained on the basis of higher triglyceride levels in the diabetics, due to their being older and more obese than the controls. However, when 83 patients with diabetes were matched with a control group for age, obesity, alcohol consumption and smoking habits, the diabetic group still had reduced mean serum HDL-cholesterol levels, albeit at a lower level of significance $(\mathrm{p}<$ 0.05 ). There was no significant difference between the serum triglyceride levels of the two groups, making it unlikely that this could account for the differences in serum HDL-cholesterol, but both diabetics and controls had rather high mean triglyceride concentrations. In order to examine the effect of diabetes alone on serum HDL-cholesterol, diabetics and controls were grouped according to the serum triglyceride concentration (Table 3). Male and female diabetics with serum triglycerides above $3.0 \mathrm{mmol} / \mathrm{l}$ had significantly lower HDL-cholesterol levels than comparably hypertriglyceridaemic non-diabetic controls. The trend was similar in the mildly hypertriglyceridaemic and normotriglyceridaemic ranges, although differences in HDL-cholesterol were not always significant. The diabetics with severe hypertriglyceridaemia had the lowest HDL-cholesterol levels. These data suggest that non-insulin dependent diabetes and hypertriglyceridaemia are independently associated with decreased HDLcholesterol levels and that a combination of both fac- tors is associated with even lower levels. This could be important, because hypertriglyceridaemia is commonly associated with untreated or poorly controlled diabetes $[18,19]$. Non-insulin dependent diabetes may be present for a considerable time before diagnosis, and during that time the patient may be exposed to severely decreased HDL-cholesterol levels. It is unlikely that differences in physical activity could account for the differences in HDL-cholesterol levels between diabetics and controls, as none of the diabetics were seriously incapacitated by vascular disease, which might have reduced physical activity. A study of the relationship between physical activity and HDL-cholesterol in the controls showed no correlation, possibly because none of the controls were taking any vigorous exercise, such as long-distance running.

Only in severely hypertriglyceridaemic females was the serum apolipoprotein A-I level significantly lower in diabetics. This is surprising, considering that this apolipoprotein is a major constituent of HDL [20-23]. This divergence between HDL-cholesterol and apolipoprotein A-I levels may reflect a difference in the HDL of untreated patients with non-insulin dependent diabetes compared to non-diabetic controls. It has been shown that HDL is composed of subfractions $\mathrm{HDL}_{2}$ and $\mathrm{HDL}_{3}$ [24], and there is evidence that $\mathrm{HDL}_{2}$ may be the subfraction protecting against the subsequent development of atherosclerosis [25]. $\mathrm{HDL}_{2}$ has a higher ratio of cholesterol to total apolipoprotein A than $\mathrm{HDL}_{3}$ [26]. The mean ratio of HDL-cholesterol to apolipoprotein A-I was significantly lower in male and female non-insulin dependent diabetics compared to matched controls $(\mathrm{p}<0.005)$, and a possible explanation of this difference is that the diabetic patients have reduced levels of the protective subfraction $\mathrm{HDL}_{2}$.

The enzyme lipoprotein lipase may have a role in the formation of HDL. In one study in man a signficant positive correlation was shown between HDLcholesterol and the activity of lipoprotein lipase in adipose tissue [27]. This enzyme is responsible for catabolising VLDL-triglyceride, and apolipoprotein $C$ is transferred from VLDL to HDL at this time [28]. Patients with non-insulin dependent diabetes have been shown to have reduced activity of lipoprotein lipase in adipose tissue, which increases after treatment with insulin [29]. It is possible that reduced activity of lipoprotein lipase in adipose tissue, perhaps secondary to insulin resistance, may account for both the decreased HDL-cholesterol levels and the hypertriglyceridaemia seen in non-insulin dependent diabetes.

Thus, serum HDL-cholesterol levels are decreased in newly presenting non-insulin dependent 
diabetics and there is no association with the degree of hyperglycaemia. The association between this type of diabetes and decreased HDL-cholesterol levels is more pronounced with concomitant hypertriglyceridaemia. Decreased HDL-cholesterol levels may be a factor contributing to premature atherosclerosis, and a follow-up study currently in progress should assess the effects of conventional therapy. The mechanism of decreased serum HDL-cholesterol levels in non-insulin dependent diabetes requires further investigation.

Acknowledgements. The authors would like to thank Dr. F. P. Roberts and the nursing staff of the Medical Department at the Lucas factory, Great King Street, Birmingham, together with all the members of the workforce who took part in the study. They wouId also like to thank Dr. K. Cross and Mrs. W. Batchelor of the Hospital Statistics Department at the Queen Elizabeth Medical Centre, Birmingham.

\section{References}

1. Gordon T, Castelli WP, Hjortland MC, Kannel WB, Dawber TR (1977) High density lipoprotein as a protective factor against coronary heart disease. Am J Med 62: 707-714

2. Lopes-Virella MFL, Stone PG, Colwell JA (1977) Serum high density lipoprotein in diabetic patients. Diabetologia 13: 285-291

3. Calvert GD, Graham JJ, Mannik T, Wise PH, Yeates RA (1978) Effects of therapy on plasma-high-density-lipoproteincholesterol concentration in diabetes mellitus. Lancet II: 66-68

4. Kennedy AL, Lappin TRJ, Lavery TD, Hadden DR, Weaver JA, Montgomery DAD (1978) Relation of high-density lipoprotein cholesterol concentration to type of diabetes and its control. Br Med J II: 1191-1194

5. Williams P, Robinson D, Bailey A (1979) High-density lipoprotein and coronary risk factors in normal men. Lancet $I$ : $72-75$

6. Wilson DE, Lees RSF (1972) Metabolic relationships among the plasma lipoproteins. Reciprocal changes in the concentrations of very-low-and low-density lipoproteins in man. J Clin Invest 51: 1051-1057

7. Castelli WP, Doyle JT, Gordon T, Hames CG, Hjortland MC, Hulley SB, Kagan A, Zukel WJ (1977) Alcohol and blood lipids. The cooperative lipoprotein phenotyping study. Lancet II: $153-155$

8. Carter T, Martin PJ, Wilding P, Goldberg DM (1976) Evaluation of a new enzymatic kit for serum triglycerides. Clin Chem 22: 520-524

9. Boehringer Corporation (London) Ltd: Fully enzymic triglyceride method. Product No 12603917

10. Richmond W (1973) Preparation and properties of a cholesterol oxidase from Nocardia sp. and its application to the enzymatic assay of total cholesterol in serum. Clin Chem 19: 1350-1356

11. Boehringer Corporation (London) Ltd: Fully enzymic (CHOD/PAP) cholesterol method. Product No 187313

12. Burstein M, Scholnick HR, Morfin RJ (1970) Rapid method for the isolation of lipoproteins from human serum by precipitation with polyanions. J Lipid Res 11: 583-595

13. Whitehead TP, Bullock DG, Carter TJN, Moore RA, Penfold W, Johnstone JH, Payne B, Gray SP, Ballantyne SC, Shepherd J, Walker G, McFarlane R, Deegan 'T (1979) High-density lipoprotein (HDL) cholesterol analysis. Ass Clin Biochem News-sheet 190: 7-10

14. Bradby GVH, Valente AJ, Walton KW (1978) Serum highdensity lipoproteins in peripheral vascular disease. Lancet II: 1271-1274

15. Kynoch PAM, Lehmann H (1977) Rapid estimation (21/2 hours) of glycosylated haemoglobin for routine purposes. Lancet II: 16

16. Miller GJ, Miller NE (1975) Plasma high-density-lipoprotein concentration and development of ischaemic heart disease. Lancet I: $16-19$

17. Taylor KG, Carter TJN, Valente AJ, Wright AD, Smith JH, Matthews KA (1981) Sex differences in the relationships between obesity, alcohol consumption and cigarette smoking and serum lipid and apolipoprotein concentrations in a normal population. Atherosclerosis 38: 11-18

18. Lewis B, Mancini M, Mattock M, Chait A, Fraser TR (1972) Plasma triglyceride and fatty acid metabolism in diabetes mellitus. Eur J Clin Invest 2: 445-453

19. Elkeles RS, Lowy C, Wyllie ADH, Young JL, Fraser TR (1971) Serum insulin, glucose and lipid levels among mild diabetics in relation to incidence of vascular complications. Lancet I: $880-883$

20. Shore V, Shore B (1968) Some physical and chemical studies on two polypeptide components of high-density lipoproteins of human serum. Biochemistry 7: 3396-3403

21. Scanu AJ, Toth C, Edelstein S, Koga, Stiller E (1969) Fractionation of human serum high-density lipoprotein in urea solutions. Evidence for polypeptide heterogeneity. Biochemistry 8: 3309-3316

22. Albers JJ, Aladjem F (1971) Precipitation of ${ }^{125}$ I-labeled lipoprotein with specific polypeptide antisera. Evidence for two populations with differing polypeptide compositions in human high density lipoproteins. Biochemistry 10: 3436-3442

23. Kostner G, Alaupovic P (1972) Studies of the composition and structure of plasma lipoproteins. Separation and quantification of the lipoprotein families occurring in the high density lipoproteins of human plasma. Biochemistry 11: 3419-3428

24. Patsch JR, Sailer S, Kostner G, Sandhofer F, Holasek A, Braunsteiner H (1974) Separation of the main lipoprotein density classes from human plasma by rate-zonal ultracentrifugation. J Lipid Res 15: 356-366

25. Gofman JW, Young W, Tandy R (1966) Ischaemic heart disease, atherosclerosis and longevity. Circulation 34: 679-686

26. Cheung MC, Albers JJ (1977) The measurement of apolipoprotein A-I and A-II levels in men and women by immunoassay. J Clin Invest 60: 43-50

27. Nikkilä EA (1978) Metabolic and endocrine control of plasma high density lipoprotein concentration. Relation to catabolism of triglyceride-rich lipoproteins. In: Gotto Jr AM, Miller NE, Oliver MF (eds) Proceedings of the Third Argenteuil Symposium, p 177-192

28. Eisenberg S, Rachmilewitz D (1975) Interaction of rat plasma very low density lipoprotein with lipoprotein lipase-rich (postheparin) plasma. J Lipid Res 16: 341-351

29. Taylor KG, Galton DJ, Holdsworth G (1979) Insulin-independent diabetes: A defect in the activity of lipoprotein lipase in adipose tissue. Diabetologia 16: 313-317

Received: July 10, 1980,

and in revised form: November 26, 1980

Dr. K. G. Taylor

The General Hospital

Steelhouse Lane

Birmingham, B4 6NH

England 